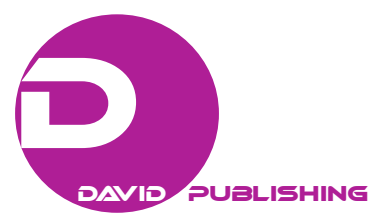

\title{
HRM in Turkey: Principles and Dimensions
}

\author{
Gürhan Uysal \\ Ondokuz Mayıs University, Samsun, Turkey
}

\begin{abstract}
Research topic of study is to discuss human resource management practices in Turkey. HRM in Turkey covers organizational climate, European context, and American-based HRM practices. Second specification might be conflict management. Firms are to develop policies for conflict management. Research methodology investigates HRM practices in Turkey through journals and HR-related magazines. Case studies are obtained from those journals. Major results are that firms strengthen organizational climate, and may pursue policies to handle conflict management. To conclude, this study aims to contribute international HRM.
\end{abstract}

Keywords: HRM, Turkish context, performance, climate, HR magazine, international HRM

\section{Introduction}

Personnel psychology is related with social relations and workplace (Arnold, 1991). It impresses attitude of employees. According to Bissen and Priya (2010), industrial psychology is related with place of work and attitudes of employees.

Personnel psychology is subsubject of industrial psychology. It is related with improving the workplace. For example, work-family balance, and job-life balance or telecommuting are associated with personnel or industrial psychology (Beatty \& Scheier, 1977). Further, the most negative impact of scientific management on employee is fatigue. Therefore, fatigue is workplace issue and related with personnel psychology.

Schneider (1987) discusses for place and person-based leadership in personnel psychology. Accordingly, personnel psychology is related with workplace. Personnel psychology affects mood of employees.

\section{Literature Review}

Importance of study is that international HRM compares distinctions between HRM in different cultures. For example, in USA off-the-job training gains priority, and in Japan, on-the-job training is important (Rynes, Gerhart, \& Parks, 2005).

\section{Research Method}

Case study method is used in the study. Three cases are adopted from Tinaz's (2009) study. And future implications determine policy of firms in HRM. Organizational climate appears on workplace through social relations. Schneider (1987) relates organizational climate with people’s job attitudes.

Model of this study:

Gürhan Uysal, Ph.D., Asc. Prof., School of Business, Ondokuz Mayıs University, Samsun, Turkey.

Correspondence concerning this article should be addressed to Gürhan Uysal, School of Business, Ondokuz Mayıs University, Kurupelit Campus, Atakum, Samsun 55139, Turkey. 


$$
\text { Personnel psychology } \Rightarrow \text { Organizational climate } \Rightarrow \text { HRM }
$$

Figure 1. Organizational climate-related HRM model.

In this model, HRM invests in personnel psychology to develop positive organizational climate. For example, democratic leadership and participative management styles may affect good mood of personnel.

Further, HRM in Turkey adopts contextual principles, and firms apply USA HRM style. Specification of Turkish HRM is organizational climate. Attitudes of employees may shape organizational climate in organizations, and it (attitude) may impress personnel psychology, which is very important in early Industrial Revolution and Taylor's era.

Firms in Turkey use European contextual variables in management of HR such as job security and health, trade unions, and other legal obligations. Therefore, HRM in Turkey is:

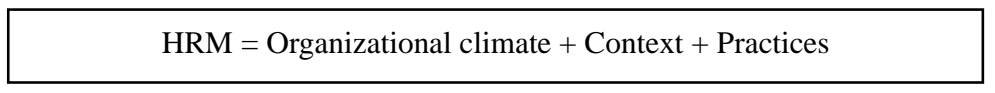

Figure 2. Context of Turkish HRM.

Behind of climate, there is personnel psychology. Therefore, firms are to implement personnel psychology policies.

\section{Constitution of Nations}

What is Industry 4.0? It may be figured with digital, technology, and human capital. Why do firms implement digital and industry 4.0? It already exists before. Because firms aim to differentiate themselves from rivals, and human capital and human resources differentiate firm in market. Therefore, most prominent quality of Industry 4.0 is human resources. Because it may differentiate firm from rivals under competition, firms may need talent management policies (Uysal, 2015).

Secondly, this paper discusses competitiveness with constitution and laissez faire. Thorstein Veblen is founder of Consitutional economy, and Adam Smith mentions for laissez faire. Laissez faire is explained with entrepreneurship. This study defends that constitution of nation may include laissez faire principles to encourage entrepreneurship in society. For example, USA citizens are free to set up new business, which is entrepreneurship, such as M. Zuckerberg and social media. Thus, laissez faire principles may be included in contitutional economy. Further, angel investment is American way of encouraging entrepreneurship. On the other hand, RISC capital method is European way. So, Europeans may prefer RISC capital strategy to encourage entrepreneurship in European Continent.

Adam Smith visited France, and talked with Quesnay and others. A. Smith obtained laissez faire from France. Smith mentioned for laissez faire in Wealth of Nations. It represents liberal economy. Smith also mentioned for Absolute Advantage of Nations in his Wealth of Nations. For example, absolute advantage of Turkey might be various and potential.

\section{Human Capital Variable}

Industry 1.0 began in 1800s, 19th century. USA and Germany joined industry 1.0 in late 19th Century. Product of industry 3.0 is maybe computers, cellular phone, and electric. Product of industry 4.0 is robots, internet, knowledge economy, electric and others. For example, firms replace electric with petrol in their factories, and firms use robot in production. Further, notable factor of Industry 4.0 may be human capital or human resources. 
Cronology of industrial development might be (Uysal, 2017):

Table 1

Chronology—Industrial Revolution

\begin{tabular}{ll}
\hline Year & Chronology \\
\hline 1800 s & 1st Industrial revolution \\
Early 1900 s & 2nd Industrial revolution \\
After 1950 & 3rd Industrial revolution \\
21st Century & 4th Industrial revolution \\
\hline
\end{tabular}

According to table, Industry 4.0 started in 2010 and it may be discussed with human capital or laissez faire. Because both may gain competitive advantage for firms.

Further, how does workforce become human capital? Human capital is related with skills and expertise. How does workforce obtain skills? On-the-job-training might be answer. American firms usually prefer off-the-job training, while Japanese firms tend to long-term employment and on-the-job training. On-the-job training may develop human capital in organizational structure.

\section{Conclusions}

To conclude, firms in Turkey may pursue policy of organizational climate to improve the impact of HRM on organization (Uysal, 2015).

There are four perspectives in international HRM: contextual, configurational, universalistic, and contingency. HRM in USA tends to configurational and universalistic perspectives. European HRM has contextual, and Chinese HRM is for contingency perspective. In addition, Turkish HRM might have three principles: organizational climate, context, and HRM practices.

\section{References}

Arnold, D. W. (1991). Potential legislative inroads into personnel psychology. Journal of Business and Psychology, 6(2), 279-282.

Beatty, R. W., \& Scheier, C. E. (1977). Personnel administration. Academy of Management Review, 2(2), 331-340.

Bissen, V., \& Priya. (2010). Industrial psychology. India: New Age International Publishers.

Rynes, S. L., Gerhart, B., \& Parks, L. (2005). Personnel psychology: Performance evaluation and pay for performance. Annual Review of Psychology, 56, 571-600.

Schneider, B. (1987). The people make the place. Personnel Psychology, 40, 437-453.

Tinaz, P. (2009). Case studies from workplaces. Istanbul: Beta Publishing.

Uysal, G. (2015). Simplex of HR: Talent management with simplex methodology. Chinese Business Review, 14(2), 87-93.

Uysal, G. (2017). HRM, organizational psychology and personnel psychology: Linear and simplex analysis of HR. Management Studies, 5(2), 149-152. 